\title{
CALVINISME EN MARXISME*
}

Die tradisionele Calvinistiese standpunt was sterk afwysend teenoor die Sosialisme, omrede van die eensydige ekonomiese (arbeids-) teorie en ateïstiese standpunt. Kuyper was egter meer simpatiek teenoor die sosiale beweging, en hy het, veral onder invloed van Bismarck, selfs leidend opgetree ten opsigte van sosiale versekering en verteenwoordiging van ekonomiese groepe.

Die moderne Calvinisme begin nou 'n ander houding inneem: daar ontstaan waardering juis vir die eensydige element van die Sosialisme, naamlik dat die arbeid hoër gewaardeer moet word en die verdeling van die rykdom gereorganiseer moet word, sodat die arbeider as verbruiker 'n groter aandeel daarin sal kry. Hierdie veranderde houding is veroorsaak deur die algemene geestesstroming van die tyd en ook deur die omstandighede van die moderne wêreld waaruit blyk dat die kapitalistiese stelsel nie meer beantwoord nie.

In die verlede wou Calviniste veelal 'n nuwe stelsel in $a b$ stracto uit die beginsel in aansyn roep - iets wat tog nie moontlik is nie. Wat moet gebeur, is die omvorming van die bestaande materie deur die beginsel.

Die twintigste eeu het inderdaad 'n nuwe orde gebring, naamlik ' $n$ meer sosiale en internasionale oriëntering van die lewe. Op grond hiervan moet erken word dat die Sosialiste elemente van die nuwe reeds vroeg raakgesien het, te wete die sosialisering en internasionalisering, en die opkoms van die vierde stand.

Die beginsel waaruit die Sosialiste werk, is egter nie vir ons as Calviniste, Afrikaners en blankes aanvaarbaar nie hulle beweging voer weg van God.

Maar tog moet dit ook gesien word as 'n ontplooiing van die menslike kultuur wat bydra tot die veelkleurigheid van die menslike geskiedenis. Wat veral gewaardeer moet word, is die gedagte dat die geringste mens nie veronagsaam mag word nie - 'n Bybelse waarheid wat deur die Christendom nie tot sy volle reg gekom het nie.

* Hierdie bydrae, wat in 1946 as lesing vir nagraadse studente in die vak Staatsleer gehou is, is nie vantevore gepubliseer nie. 
In die geskiedenis kan heelwat voorbeelde aangetoon word van Christelike beweginge wat die goeie elemente van hulle tyd in hulleself opgeneem het. Die Hervorming was ten nouste met die Renaissance verbonde; en Kuyper se optrede het saamgeskakel met die Franse Revolusie en die hele Liberale beweging van die negentiende eeu, en die vrugte van dié bewegings ingesamel, byvoorbeeld die idee van 'n vrye kerk in ' $n$ vrye staat, en algemene stemreg. Hierdie dinge is aanvaar met uitsuiwering van die aanstootlike elemente.

\section{II}

Die gebreke van die Marxistiese teorie word daagliks voorgehou, byvoorbeeld die ateïsme, materialisme, die ekonomiese dwaalleringe (arbeid as die enigste voortbrenger van rykdom, en die kapitalisme as die enigste stelsel van uitbuiting); ook die gebreke van die Sosialistiese maatskappy wat die bestaande moet vervang, en die internasionalisme.

Desnieteenstaande het die Marxistiese Sosialisme 'n belangrike historiese rol te vervul, en wel om die volgende verdienstelike elemente:

Geen ander beweging het die aandag so pertinent gevestig op dié gebrek van die bestaande stelsel, naamlik die onmenswaardige behandeling van die (hand-)arbeider. Indien dit nog deur ander beweginge raakgesien is, is dit as onvermydelik beskou. Maar die Sosialiste het dit deur woord en geskrif op die felste manier blootgelê, selfs deur verset te organiseer.

Verder is deur die Sosialiste aangetoon dat die kapitalistiese produksiewyse ekonomies ook onvoordelig is deur die periodieke krisisse en die skepping van 'n produksieapparaat wat nie ten volle in die werk gestel kan word nie: ter wille van winste moet dit skaarste bewerk.

Hierdie euwels is nie alleen aan die lig gebring nie, maar daar is aangetoon dat hulle noodwendige uitvloeisels van die kapitalistiese stelsel self is, omdat die nadruk op kapitaal (geld) en wins val. Produksie word eensydig beklemtoon ten koste van distribusie; en in die produksieproses val die nadruk eensydig op die faktor kapitaal.

Die noodwendige gevolg hiervan is besonder verskerp deur die ontwikkeling van die tegniek, waardeur arbeid al meer en meer oortollig word. Weens werkloosheid en vermin- 
derde koopkrag is die mensdom al minder in staat om deur die verhoogde produksie te baat, en moet die produksie eindelik weer ingekort word.

In verband met die staat is die volgende twee waarhede aan die lig gebring:

Eerstens: Die staat van die negentiende eeu is nie 'n modelstaat vir alle tye nie, maar slegs verbind met 'n sekere tyd.

Tweedens: Die staat, soos tot nog toe bekend, is 'n essensiële deel van die kapitalistiese stelsel: dit het sy vorm daardeur verkry en is eintlik die middel om dit te handhaaf. Dit sluit in dat die staat nie die menslike samelewing in sy geheel is nie maar slegs 'n aspek daarvan.

Daar is verder raakgesien dat die stelsel van politieke, ekonomiese en sosiale organisasie nie in sigself noodwendig of altyddurend is nie, maar dat dit net een vorm is waarin die menslike samelewing op dié gebiede georganiseer kan word. Die mensdom kan dus van die euwels verlos word, maar dan deur radikale omvorming. Om dit te bewys het hulle historiese ondersoekinge aangepak en bewyse uit die verlede aangevoer.

Die Sosialiste het aangetoon dat hierdie stelsel noodwendig moet verbygaan, omdat dit in homself die kieme van verval dra, deurdat dit tot botsings en krisisse lei. Die verval is dus nie 'n vrome wens of 'n etiese behoefte nie, maar 'n historiese noodwendigheid.

Hiermee hang saam die leerstuk van die historiese materialisme: dat die samelewingsvorm en geestesstruktuur medebepaal word deur ekonomiese toestande, 'n waarheid wat reeds deur Aristoteles raakgesien is.

Selfs die vorm van die toekomstige organisasie van die samelewing is in hoofsaak (nie in besonderhede nie) korrek gesien, naamlik 'n vorm waarin die produksiemiddele grotendeels gemeenskaplik beheer sal word; en dat die staat hom hierby in meer koöperatiewe vorm sal aanpas. Dit is deur die Russiese praktyk as moontlik bewys.

Die Marxisme is aan die ander kant ook deur die feite beïnvloed, byvoorbeeld die erkenning van nasionaliteite in Rusland.

Eindelik kan genoem word die besef dat die toekomstige staat internasionaal (nie kosmopolities) sal wees en meer ge- 
integreer. (Vergelyk Rusland en die Britse Statebond).

Die Marxisme het dus meer as enige ander beweging aan die behoefte van die tyd beantwoord. Ten opsigte van bostaande is die stryd dan ook afgeloop. Maar dit word voortgesit ten opsigte van die volgende twee sake:

Eerstens: of dit werklik noodsaaklik is om alle produksiemiddele te sosialiseer, en of private inisiatief nie op 'n groot terrein behou kan word nie, soos by die Fascisme en NasionaalSosialisme.

Tweedens: die mate van gesag wat by die leiers van die gemeenskap gevind moet word. Die vraag is of 'n gesosialiseerde staat demokraties kan bly.

Potchefstroom.

L. J. du Plessis. 